\title{
MULTIPLE LOGISTIC REGRESSION ON FACTORS AFFECTING LOW BACK PAIN AMONG OUTPATIENTS IN THE PHYSICAL REHABILITATION POLYCLINIC
}

\author{
Septi Ayu Arum Yuspita Sari'), Dono Indarto²), \\ Mahendra Wijaya ${ }^{3}$ \\ ${ }^{1)}$ Masters Program in Public Health, Universitas Sebelas Maret \\ 2)Department of Physiology, Faculty of Medicine, Universitas Sebelas Maret \\ 3)Faculty of Social and Political Sciences, Universitas Sebelas Maret
}

\begin{abstract}
Background: Low back pain (LBP) is one of top ten disorders in the world. However, the prevalence remains unclear due to the first attack happening in adult age. Some biological factors increase the risk of LBP while education level, occupation and knowledge about LBP have not been investigated yet. This study aimed to analyze factors affecting LBP such as age, sex, education level, occupation, and knowledge about LBP.

Subjects and Method: This was a case-control study conducted in Physical Rehabilitation Policlinic, Dr. Moewardi Hospital, Surakarta, Central Java, from October to November 2018. A sample of 150 outpatients was selected fixed exposure sampling. The dependent variable was LBP. The independent variables were age, sex, education, occupation, and knowledge about LBP. Data on LBP were obtained from medical record. The other data were collected by questionnaire. The data were analyzed by a multiple logistic regression.

Results: Female $(\mathrm{OR}=1.11 ; 95 \% \mathrm{CI}=1.08$ to $8.62 ; \mathrm{p}=0.036)$, severe occupation (OR= $1.83 ; 95 \% \mathrm{CI}=2.29$ to $16.96 ; \mathrm{p}<0.001)$, and older age $(\mathrm{OR}=2.59 ; 95 \% \mathrm{CI}=4.70$ to 37.37; $\mathrm{p}<0.001)$ increased the risk of LBP. Higher education $(\mathrm{OR}=-2.04 ; 95 \% \mathrm{CI}=0.05$ to $0.40 ; \mathrm{p}=0.009)$ and higher knowledge of $\mathrm{LBP}(\mathrm{OR}=-1.30 ; 95 \% \mathrm{CI}=0.10$ to $0.72 ; \mathrm{p}=$ o.009) reduced the risk of LBP.
\end{abstract}

Conclusion: Female, severe occupation, and older age increase the risk of LBP. Higher education and higher knowledge reduce the risk of LBP.

Keywords: Low back pain, age, occupation, gender

\section{Correspondence:}

Septi Ayu Arum Yuspita Sari. Masters Program in Public Health. Universitas Sebelas Maret, Jl. Ir. Sutami 36 A, Surakarta 57126, Central Java. Email: yuspitasario20993@gmail.com. Mobile: +6282338986991.

The $5^{\text {th }}$ International Conference on Public Health Best Western Premier Hotel, Solo, Indonesia, February 13-14, 2019 | 68 https://doi.org/10.26911/theicph.2019.01.14 